\section{AGRIEKONOMIKA}

http://journal.trunojoyo.ac.id/agriekonomika

Volume 10, Nomor 1, 2021

https://doi.org/10.21107/agriekonomika.v10i1.9982
Agriekonomika has been accredited as a scientific journal by the Ministry of

Research-Technology and Higher

Education Republic of Indonesia: No. 23/E/KPT/2019

\title{
Mengungkap Makna "Keuntungan"pada Sistem Paroan Penggemukan Sapi Madura
}

\author{
${ }^{\otimes}$ Bambang Haryadi, Hanif Yusuf Seputro, Habi Bullah \\ Jurusan Akuntasni Fakultas Ekonomi dan Bisnis \\ Universitas Trunojoyo Madura, Indonesia
}

Received: Februari 2021; Accepted: April 2021; Published: April 2021

\begin{abstract}
ABSTRAK
Pulau Madura terkenal sebagai pulau sapi karena populasi budidaya sapi yang masif. Budidaya sapi sudah lama dikembangkan dengan pola kerjasama (paroan). Tujuan penelitian untuk mengungkap faktor yang mempengaruhi penggemukan sapi, model konsep bisnis "Paroan"dan makna keuntungan nilai serta makna di balik keuntungan. Penelitian ini menggunakan model mix method yang memadukan pendekatan kuantitatif dan kualitatif. Model kualitatif digunakan setelah penelitian kuantitatif dilakukan. Hasil analisis regresi berganda menunjukkan bahwa konsep keuntungan memiliki pengaruh terhadap perkembangan bisnis sistem paroan. Secara kualitatif, terdapat 2 konsep paroan yaitu paroan uang dan paroan hasil anak sapi. Jenis keuntungan berupa keuntungan material dan non material. Keuntungan materi dimaknai sebagai usaha mencari uang atau rejeki, sebagai penghasilan tambahan, sebagai tabungan. Sedangkan non materi dimaknai sebagai: (1) anugerah produktivitas, (2) bersama beramal, (3) menyambung saudara, (4) menjunjung tinggi budaya.
\end{abstract}

Kata kunci: Sapi, Paroan, Madura, Mix Method, Fenomenologi.

Unveiling the "Accounting Profits" of Madura Cattle Fattening "Paroan" System

\begin{abstract}
Madura Island is famous as a cow island because of its high cattle cultivation. Cattle cultivation has long been developed with a cooperative ("paroan") pattern. The research objective was to reveal the factors that influence cattle fattening, the type of "Paroan" business concept, and the type of profit, value, and meaning behind the gain. This study uses a mixed-method model that combines quantitative and qualitative approaches. The test results show that the concept of profit influences the business development of the half system. There are two concepts: half of the money, half of the money, and half of the calves. Types of benefits include material and non-material services. Material gain is interpreted to find the leading fortune, as additional income, as savings. Meanwhile, nonmaterial is interpreted as (1) a gift of productivity, (2) collective charity, (3) connecting siblings, (4) upholding a culture.
\end{abstract}

Keywords: Cow, Paroan, Madura, Mix Method, Phenomenology.

\section{PENDAHULUAN}

Berbicara tentang Madura memang tidak bisa dilepaskan dari tradisi karapan sapi. Suatu tradisi di Madura yang telah terkenal di dunia. Karapan sapi adalah suatu kearifan lokal pula Madura yang memiliki ciri khas yang unik dan diakui masyarakat internasional. Hal itu mendorong jumlah sapi di Madura relatif melimpah selain untuk tujuan karapan juga untuk sapi potong.

\footnotetext{
Corresponding author:

Email : bambang.haryadi@trunojoyo.ac.id
} 
Bahkan Propinsi Jawa Timur menjadikan pulau ini sebagai pula sapi dikarenakan pulau ini memiliki kontur tanah serta iklim yang sangat mendukung kehidupan dan budi daya sapi. Pusat Data dan Informasi Kementan (2018), menunjukkan bahwa pusat populasi sapi potong Jawa Timur merupakan propinsi yang memiliki tingkat kontribusi yang besar yaitu mencapai ratarata 4,39 juta ekor. Dari jumlah sapi potong di Jawa Timur itu ternyata pulau Madura merupakan daerah yang berkontribusi sangat besar hingga mencapai 974.548 ekor sapi (BPS, 2017).

Sapi di Madura menghasilkan kualitas daging sapi yang bagus, berkualitas premium (Kutsiyah, 2012; Nurlaila dkk., 2018). Daging sapi madura menurut para ahli memiliki keistimewaan tersendiri. Tekstur dari dagingnya lembut, kemudian memiliki warna merah cerah dan bisa terlihat dagingnya segar, empuk, serta rendah lemak yang dikandungnya (Firmansyah \& Sunyigono, 2020).

Ini semua tidak bisa dilepaskan dari kehidupan masyarakat lokal yang sangat menhargai sapi karena memiliki nilai kultural, sejarah yang sangat tinggi bagi masyarakat Madura.

Secara umum definisi keuntungan atau laba adalah kenaikan manfaat ekonomi yang diperoleh selama periode akuntansi, kenaikan aset atau penurunan kewajiban yang menghasilkan peningkatan ekuitas (Themin, 2012). Keuntungan juga bermakna atau laba didefinisikan oleh para ahli akuntansi sebagai kelebihan pendapatan di atas beban yang dikeluarga dalam suatu kegiatan bisnis (Richard dkk., 2020).

Dalam perkembangannya, pemaknaan laba tidak lagi ditinjau dari sudut materi, namun juga dari non materi (Subiyantoro \& Triyuwono, 2004; Triyuwono, 2017). Keuntungan didefinisikan menjadi lebih humanis dan religius dan tidak selalu bermakna materi. Keuntungan merupakan seluruh manfaat baik materi maupun non materi yang diperoleh tidak hanya pihak manajemen, namun juga pihak lain misalkan pekerja, masyarakat dan lingkungan sekitar, termasuk alam semesta.

Usaha ternak atau budidaya sapi telah banyak dikembangkan oleh masyarakat Madura dengan pola kerjasama dan menghasilkan keuntungan, termasuk penggemukan sapi. Proses penggemukan sapi secara kultural dilakukan tidak sendiri oleh para pemilik sapi. Namun dilakukan dengan cara kerjasama yang disebut dengan "Sistem Paroan". Dalam perkembangannya sistem ini telah menjadi tradisi bisnis di pulau Madura. Sudah berpuluh-puluh tahun umurnya tradisi ini melekat dalam kehidupan ekonomi di pulau Madura.

Menyadari bahwa "sistem paroan" ini adalah merupakan perkembangan sistem bisnis lokal yang harus dibudidayakan, maka peneliti tertarik untuk mengangkatnya sebagai riset budaya. Peneliti meyakini bahwa dalam sistem bisnis ini pasti memiliki nila-nilai luhur keuntungan bagi seluruh pihak. Selanjutnya setelah peneliti menemukan nilai-nilai luhur dalam ekonomi (akuntansi) maka akan diungkap makna yang terkandung di dalam nilai-nilai tersebut.

Beberapa penelitian tentang makna keuntungan dilakukan oleh Mursy \& Rosidi (2013), yang bertujuan mengungkap makna laba melalui kebiasaan, adat istiadat, dan ritual di rumah sakit. Hasil penelitian menunjukkan bahwa pemaknaan laba adalah sebagai bentuk abstrak yang berupa rasa syukur dan rasa bahagia serta penebar rasa bahagia.

Penelitian senada juga dilakukan oleh Ubaidillah dkk. (2013), yang berhasil mengungkap makna keuntungan bagi pedagang kaki lima di Bangsri Jepara. Penelitian tersebut menyatakan bahwa terdapat tiga makna keuntungan, yaitu "keuntungan materi", "keuntungan spiritual", dan "keuntungan kepuasan batin". Penelitian Mursy \& Rosid (2013), tentang eksplorasi makna laba pada Rumah Sakit Aisyiyah, bahwa makna laba sebagai bentuk fisik berupa uang atau materi, alat untuk membayar kewajiban rumah sakit pasa pihak eksternal, alat 
untuk meningkatkan kesejahteraan, untuk mendanai dakwah Muhammadiyah.

Meskipun sudah ada beberapa penelitian tentang mengungkap makna keuntungan serta bagi hasil peternakan khususnya sapi, ternyata belum banyak menyentuh sistem bisnis budaya dan lebih banyak berfokus pada bagaimana perjanjian dan proses bagi hasil usaha ternak (Ikhsan dkk., 2018; Yarmunida, 2018).

Sapi Madura salah satu jenis sapi yang relatif lebih komplit kebermanfaatannya. Guntoro (2012), menyebutkan bahwa sapi Madura merupakan hasil persilangan jenis sapi Bali (Bos Sundaicus) dengan jenis sapi Gir (Mysore). Ciri khasnya menurut Karnaen \& Arifin (2007), adalah sifat reproduksi maupun sifat produksi pada musim kemarau berbeda dibandingkan dengan sifat reproduksi dan sifat produksi pada musim hujan. Itulah mengapa masyarakat Madura memiliki kelebihan senang memelihara dan beternak sapi (Aziz, 2019).

Secara umum proses penggemukan sapi potong dimulai dari membeli sapi bakalan jantan berumur antara 2 tahun sampai 2,5 tahun untuk digemukkan selama 3 sampai 4 bulan, kemudian dijual kembali. Berbeda dengan usaha pembibitan, dimana kegiatannya dimulai dengan memelihara sapi induk hingga dewasa dan menghasilkan bibit-bibit baru sapi bakalan untuk digemukkan.. Besarnya keuntungan diperoleh jika dapat menggemukan sapi dengan pemberian pakan yang lebih efisien. Misalkan dengan memberi pakan berupa konsentrat dan limbah pertanian, peternak dapat menghemat biaya pakan (Sudarmono \& Sugeng, 2016).

Berkenaan dengan aspek budaya, Abdoellah (2020), menyataan bahwa budaya merupakan hasil rekayasa manusia setempat dan bersifat kultur dipunyai oleh sekelompok masyarakat di daerah dan berkembang dengan daya nalar dan karakter manusia. Perkembangan sebuah budaya sangat dipengaruhi oleh faktor kompetensidasar (basic competence) yang meliputi kompetensi spiritual, kompetensi berbasis literasi ilmu pengetahuan, kompetensi belajar untuk belajar.

Topik penelitian tentang sapi telah banyak dilakukan misalnya oleh Kutsiyah (2012), tentang proses pembibitan sapi potong di Madura. Hasilnya bahwa pembibitan sapi ditentukan oleh sistem seleksi kearah pemanfaatan sapi Madura unggul (sapi Sonok dan sapi karapan), pelestarian plasma nutfah sapi Madura di Pulau Sapudi, dan kehati-hatian dalam pelaksanaan program persilangan sapi Madura dengan sapi exotic. Selanjutnya oleh Sahala dkk. (2016), dan Sunarto dkk. (2016), tentang jumlah kepemilikan sapi potong yang dipengaruhi oleh luas lahan pertanian, pengalaman usaha serta jumlah ketersediaan tenaga kerja. Sedangkan Nurwahidah dkk. (2015), meneliti tentang pengaruh pemberian pakan konsentrat dan urea molases blok (UMB) terhadap pertambahan berat badan sapi potong,

Penelitian akuntansi dengan objek sapi dilakukan oleh Rahayu (2013), rata-rata pendapatan peternak selama satu tahun sebesar Rp.7.803.395,833 yang artinya usaha ternak sapi perah bisa dipertahankan sebagai sumber pendapatan. Nugraha (2014), menunjukkan bahwa ketiga perlakuan akuntansi atas aset biologis tersebut memiliki banyak sekali perbedaan. Sedangkan Muyasaroh dkk. (2015), serta Pratiwi \& Sudaryanti (2016), yang senada penelitiannya bahwa masyarakat Madura mengikuti perlombaan Karapan Sapi ini sebagai bentuk kecintaan dan pelestarian nilai budaya khususnya Madura. Paramiswari \& Hayati (2017), menunjukkan peternak di Desa Kapedi berada pada tingkat umur produktif, tingkat pendidikan SD/MI, lama pengalaman sekitar 10-20 tahun, sedangkan riset akuntansi tentang nilai dan makna dilakukan oleh Hafni (2017), menunjukkan bahwa akuntansi yang dilakukan oleh wirausahawan adalah dalam bentuk catatan keuangan dan memori. Kemudian Sakri et al. (2018), bahwa masing-masing informan menganggap bahwa akuntansi hanya untuk perusahaan besar saja karena akuntansi untuk usaha informal 
belum dipelajari di sekolah. Adapun Zahri \& Haryadi (2019), menunjukkan bahwa: (1) Pemilik tak selalu berharap keuntungan materi (2) Yakin rejeki dari allah (3) Keuntungan non materilah yang dicari. Meraih Keutamaan Akhirat, bisa menyanyangi, melayani sapi dengan baik, tidak menyiksa terhadap hewan peliharaan

Berdasarkan riset-riset sebelumnya dapat disimpulkan bahwa penelitian ini memiliki perbedaan yang cukup signifikan. Riset tentang menyingkap nilai dan makna akuntansi "sistem paroan" penggemukan sapi Madura dengan pendekatan Fenomenologi ini sepanjang pemantauan peneliti belum pernah dilakukan oleh peneliti-peneliti sebelumnya. Selama ini riset bidang akuntansi belum mengarah pada upaya mengungkap nilai dan makna sistem penggemukan sapi dengan model paroan. Selain itu riset tentang pendapatan akuntansi penggemukan sapi sebatas pada profitabilitas saja, belum dilihat makna di dalam memperolehnya.

Oleh karena itu tujuan dari penelitian ini adalah untuk (1) memperoleh gambaran tentang proses penggemukan sapi dengan metode paroan di budaya Madura. Kemudian (2) menentukan faktor apa saja yang mempengaruhi "sistem paroan".
Serta (3) mengetahui jenis bisnis dan keuntungan yang diperoleh serta makna apa saja yang terkandung di balik keuntungan.

\section{METODE PENELITIAN}

Pendekatan penelitian yang digunakan adalah metode campuran atau perpaduan kuantitatif dan kualitatif (mix method). Perpaduan baik pada tahap pengumpulan data maupun semua tahapan proses penelitian (Creswell, 2014; Tashakkori \& Teddlie, 2010). Dengan pendekatan ini akan mendapatkan sebuah fakta hasil riset yang komprehensif dan lebih bagus, lebih leluasa menggali dan menjawab riset dan saling menguatkan dengan menggunakan berbagai alat riset yang ada (Mertens, 2010).

Penelitian ini menggunakan salah satu model mix method yang di kemukakan oleh Creswell (2014), yaitu Embedded Correlation Model. Model ini nantinya akan digunakan dalam waktu yang berbeda yaitu saat setelah penelitian kuantitatif dilakukan. Alasan pemilihan model ini karena tujuan dalam penelitian ini adalah pendekatan kualitatif akan memperkuat atau mendukung riset kuantitatif yang telah dilakukan sebelumnya.

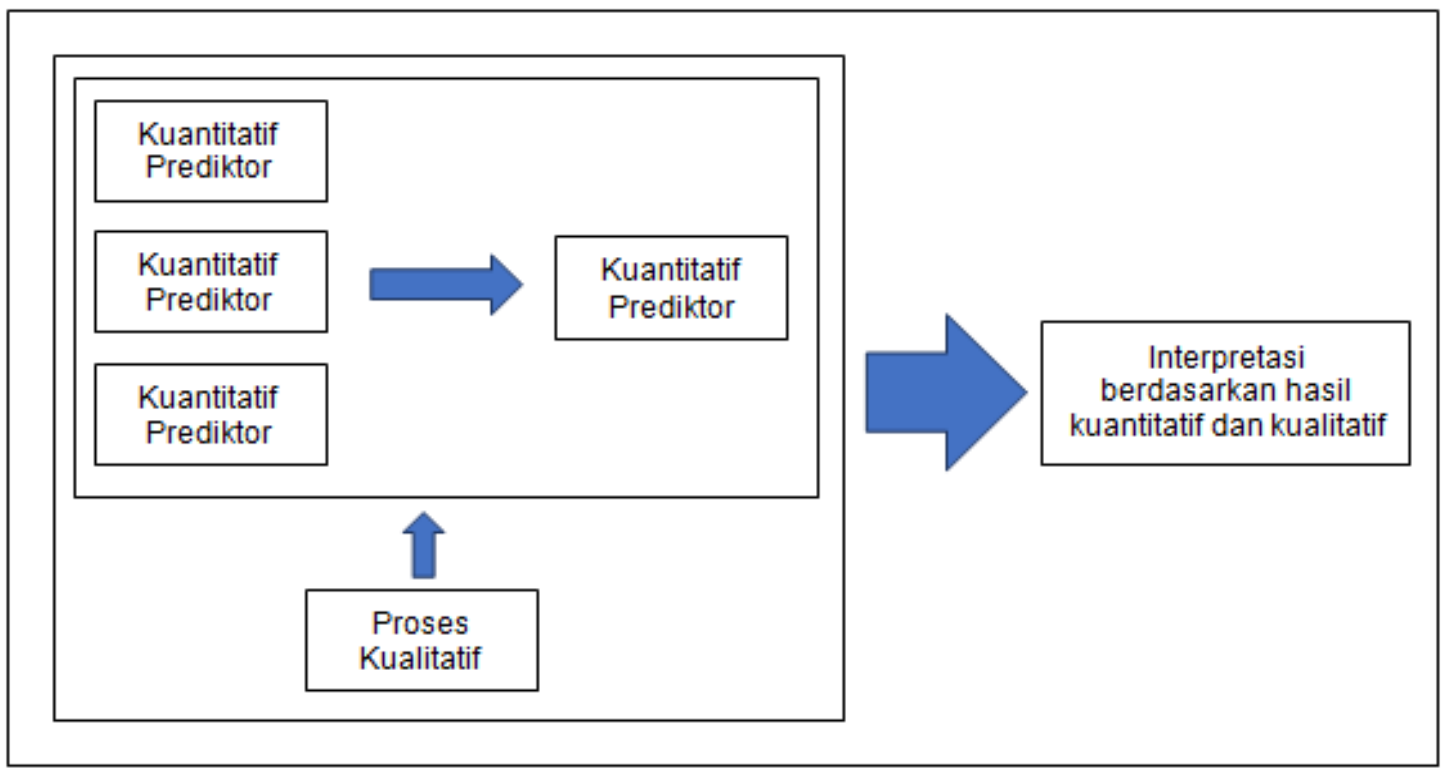

Sumber: Creswell (2014)

Gambar 1

Proses Mix Method 


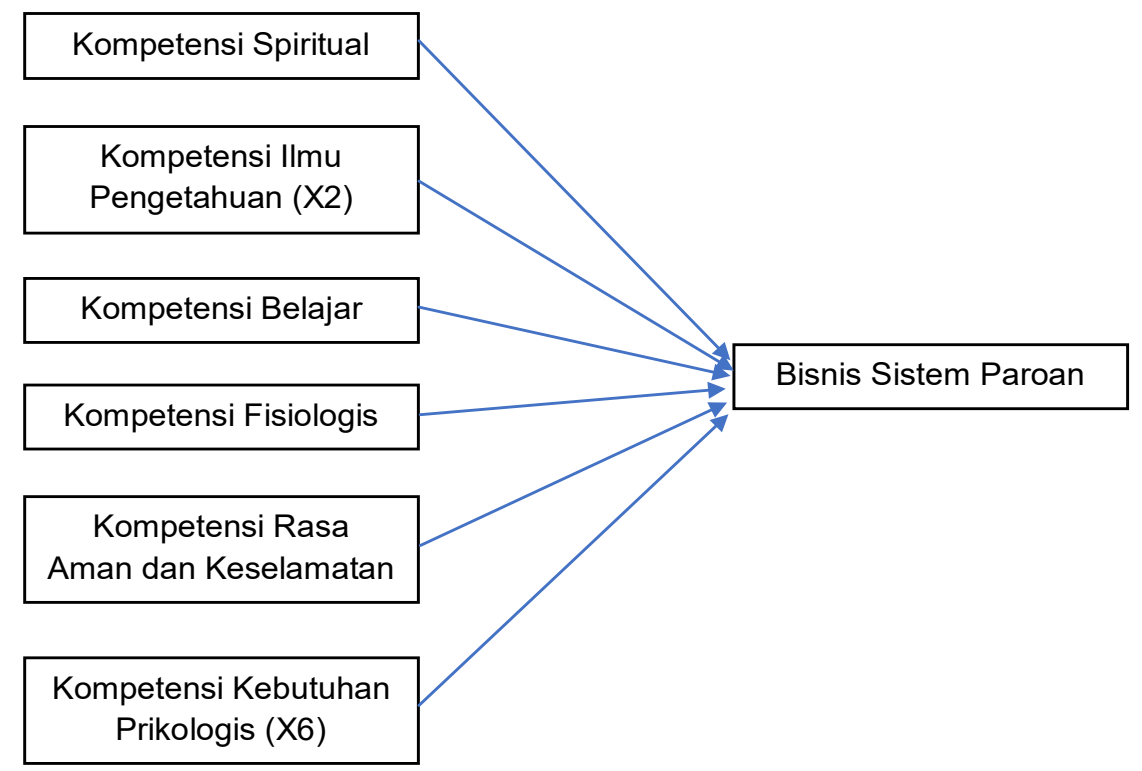

Sumber: Data Primer Diolah, 2021

Gambar 2

Model Uji Kuantitatif (Regresi Berganda)

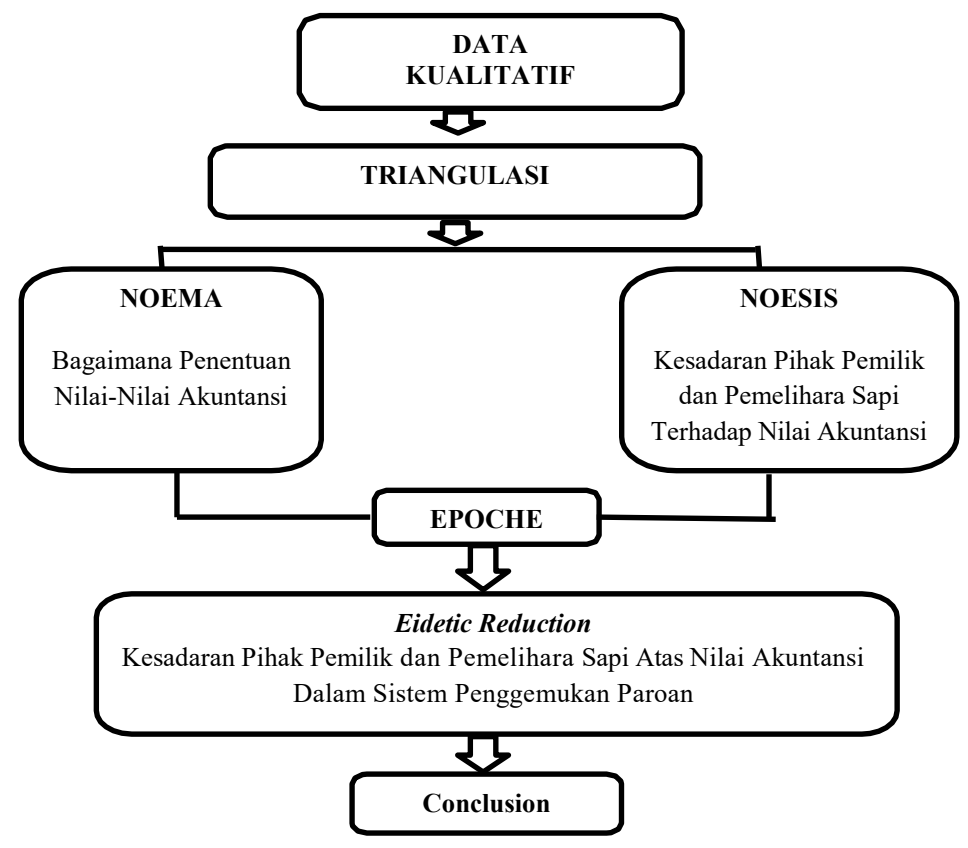

Sumber: Creswell (2014)

Gambar 3

Proses Fenomenologi

Peneliti akan menggunakan metode uji regresi dalam menguji faktor-faktor apa saja yang mempengaruhi keberadaan "sistem paroan". Sebagai prasyarat dalam pengujian hipotesis maka penelitian di awal akan melakukan uji asumsi klasik. Disamping itu secara deskriptif nanti akan dilakukan pengujian jenis-jenis konsep bisnis "Paroan" yang ada dan berkembang dalam tradisi penggemukan sapi di Madura. Model pengujian yang dikembangkan oleh peneliti yaitu dijabarkan pada gambar berikut. 
Populasi pada penelitian ini yaitu Pembudidaya Sapi Sistem Paroan yang ada di Pulau Madura yang tersebar di 4 Kabupaten dengan sampel yang berhasil dikumpulkan yaitu 236 sampel penelitian. Data kuantitatif dikumpulkan dengan menggunakan kuesioner menggunakan skala likert.

Uji fenomenologi digunakan sebagai bagian dari pendekatan mix method. Uji ini bertujuan untuk memotret lebih dekat mengenai kesadaran pemilik dan penggemuk sapi dalam memaknai nilai keuntungan. Fenomenologi mencoba menjelaskan atau mengungkapkan konsep pemaknaan dan pengalaman fenomena yang didasari atas kesadaran individu( Auliyah, 2014; Moleong, 2017).

Uji kualitatif, peneliti meng-gunakan metode pengumpulan data dengan melakukan observasi (pengamatan) dan wawancara. Beberapa hal utama dalam metode analisis data fenomenologi transcendental yang harus dipahami menurut Kamayanti (2016), yaitu: 1) Noema; 2) Noesis; 3) Ephoche (Bracketing); 4) Intentional Analysis; 5) Eidetic Reduction. Terakhir, peneliti akan mendapatkan hasil dari seluruh proses yang dilakukan dan dapat menyimpulkan fenomena yang disebut eidetic reduction. Eidetic reduction merupakan proses menemukan intisari esensi dari hakikat kesadaran atau pengalaman dengan refleksi penelitian(Hardiansyah, 2013). Proses menemukan esensi noetic/ noumatic corelates untuk mengungkap esensi atau makna keseluruhan dari fenomena yang diteliti.

Novelty penelitian ini adalah menggunakan pendekatan mix method. Metode kuantitaif digunakan untuk mengetahui faktor yang mempengaruhi sistem paroan, dan fenomenologi untuk memperdalam jenis dan makna keuntungan yang diperoleh petani dalam sistem tersebut. Sehingga rumusan masalah riset ini adalah (1) faktor apa saja yang mempengaruhi "sistem paroan" dalam penggemukan sapi? (2) Jenis bisnis dan keuntungan serta makna yang diperoleh dalam penggemukan sapi.

\section{HASIL DAN PEMBAHASAN \\ Hasil pengujian Secara Kuantitatif}

Penelitian ini dilakukan di Kabupaten Sumenep yang luas wilayah kabupaten ini sekitar 2.093,45 $\mathrm{km}^{2}$, dengan jumlah populasi masyarakatnya kurang lebih 1.041.915 jiwa (BPS Kabupaten Sumenep). Penelitian kuantitatif dilakukan di 27 kecamatan di Kabupaten Sumenep, 2021, sedangkan penelitian kualitatif sebagai pelengkap dilakukan di desa Lalangon Kecamatan Manding Kabupaten Sumenep.

Jumlah responden ditentukan dengan system keterwakilan dari 27 kecamatan yang ada. Maka diperkirakan akan ada responden sebanyak 270. Jumlah responden yang berhasil ditemui dan mengembalikan kusioner kepada peneliti sebanyak 265 sedangkan sisanya sebanyak 5 kuisioner tidak dikembalikan oleh responden dengan berbagai alasan karena kesibukan dan lain sebagainya.

Uji statistik $F$ dalam riset ini menunjukkan bahwa variabel $\mathrm{X} 1$ sampai dengan $\mathrm{X} 6$ mempengaruhi perkembangan bisnis sistem paroan (Y) dalam penggemukan sapi Madura secara simultan. Adapun uji model regresi menunjukkan bahwa nilai $R$ Square bernilai 0,845 yang berarti bahwa besarnya pengaruh semua variabel $X$ terhadap $Y$ yaitu bernilai $84,5 \%$. Sedangkan sisanya yaitu $15,5 \%$ dipengaruhi oleh faktor lainnya. Uji t untuk menguji tingkat atau besarnya pengaruh satu variabel independen secara individual dalam menjelaskan variabel dependen yaitu perkembangan bisnis sistem paroan nilai probabilitas t lebih kecil dari 0.05 maka hipotesis diterima.

Uji t dalam riset ini dilakukan bertujuan untuk menguji tingkat atau besarnya pengaruh satu variabel independen secara individual yaitu variable kompetensi spiritual (X1), kompetensi literasi ilmu pengetahuan: konsep keuntungan (X2), kompetensi belajar untuk belajar (X3), kebutuhan 
fisiologis (X4), kebutuhan rasa aman dan keselamatan (X5), kebutuhan psikologis (X6) dalam menjelaskan variabel dependen yaitu perkembangan bisnis sistem paroan. Hasil pengujian sebagaimana dalam Tabel 4.5 menggambarkan jika nilai probabilitas t lebih kecil dari 0.05 maka hipotesis diterima.

Berdasarkan hasil uji t pada Tabel 1 menunjukkan pengaruh variabel-variabel independen terhadap perkembangan bisnis sistem paroan $(\mathrm{Y})$ penggemukan sapi Madura. Hasilnya adalah sebagai berikut:

a. Kompetensi Spiritual (X1) memiliki tingkat signifikansi sebesar 0,756 yang berarti nilainya lebih besar dari nilai signifikan 0,05 . Ini berarti bahwa Kompetensi Spiritual (X1) tidak memiliki pengaruh signifkan terhadap Perkembangan Bisnis Sistem Paroan (Y).

b. Kompetensi Literasi Ilmu Pengetahuan: Konsep Keuntungan (X2) memiliki tingkat signifikansi sebesar 0,000 yang berarti nilainya lebih kecil dari nilai signifikan 0,05. Ini berarti bahwa Kompetensi Literasi IImu Pengetahuan: Konsep Keuntungan (X2) memiliki pengaruh signifkan terhadap Perkembangan Bisnis Sistem Paroan (Y). c. Kompetensi Belajar untuk belajar (X3) memiliki tingkat signifikansi sebesar 0,007 yang berarti nilainya lebih kecil dari nilai signifikan 0,05. Ini berarti bahwa Kompetensi Belajar untuk belajar (X3) memiliki pengaruh signifkan terhadap Perkembangan Bisnis Sistem Paroan ( $\mathrm{Y}$ ).

d. Kebutuhan Fisiologis (X4) memiliki tingkat signifikansi sebesar 0,000 yang berarti nilainya lebih kecil dari nilai signifikan 0,05 . Ini berarti bahwa Kebutuhan Fisiologis (X4) memiliki pengaruh signifikan terhadap Perkembangan Bisnis Sistem Paroan (Y).

e. Kebutuhan Rasa Aman dan Keselamatan (X5) memiliki tingkat signifikansi sebesar 0,406 yang berarti nilainya lebih besar dari nilai signifikan 0,05. Ini berarti bahwa Kebutuhan Rasa Aman dan Keselamatan (X5) tidak berpengaruh signifikan terhadap Perkembangan Bisnis Sistem Paroan (Y).

f. Kebutuhan Psikologis (X6) memiliki tingkat signifikansi sebesar 0,726 yang berarti nilainya lebih besar dari nilai signifikan 0,05. Ini berarti bahwa Kebutuhan Psikologis (X6) tidak berpengaruh signifikan terhadap Perkembangan Bisnis Sistem Paroan (Y).

Tabel 1

Uji T

Coefficients $^{\mathrm{a}}$

\begin{tabular}{|c|c|c|c|c|c|c|c|c|}
\hline & \multirow{2}{*}{ Model } & \multicolumn{2}{|c|}{$\begin{array}{c}\text { Unstandardized } \\
\text { Coefficients }\end{array}$} & \multirow{2}{*}{$\begin{array}{c}\begin{array}{c}\text { Standardized } \\
\text { Coefficients }\end{array} \\
\text { Beta }\end{array}$} & \multirow{2}{*}{$\mathrm{t}$} & \multirow{2}{*}{ Sig. } & \multicolumn{2}{|c|}{$\begin{array}{l}\text { Collinearity } \\
\text { Statistics }\end{array}$} \\
\hline & & $B$ & $\begin{array}{l}\text { Std. } \\
\text { Error }\end{array}$ & & & & Tolerance & VIF \\
\hline \multirow[t]{7}{*}{1} & (Constant) & 1,364 & ,956 & & 1,426 & ,155 & & \\
\hline & Spirit (X1) & ,006 & ,018 & ,008 & ,310 & ,756 & ,951 & 1,051 \\
\hline & Untung (X2) &, 595 & ,024 & ,795 & 25,256 & ,000 & ,608 & 1,644 \\
\hline & Belajar (X3) & ,050 & ,018 & 071 & 2,718 & ,007 & ,884 & 1,131 \\
\hline & Fisio (X4) & ,062 & ,012 & 156 & 5,113 & ,000 & ,646 & 1,547 \\
\hline & Aman (X5) & ,015 & ,018 & ,021 & ,832 & ,406 & ,958 & 1,044 \\
\hline & Psiko (X6) &,- 005 & ,015 &,- 009 &,- 350 & ,726 & ,943 & 1,060 \\
\hline
\end{tabular}

a. Dependent Variable: Paroan (Y)

Sumber: Data Diolah, 2021 
Kompetensi Spiritual (X1) Tidak Berpengaruh terhadap Perkembangan Bisnis Sistem Paroan (Y).

Berdasarkan hasil uji hipotesis yang dilakukan, terdapathasil bahwa kompetensi spiritual tidak berhasil memperoleh pengaruh yang signifikan terhadap perkembangan bisnis sistem paroan. Hal ini tidak sejalan dengan beberapa penelitian yang dilakukan oleh Ludin \& Saleh (2018); Paisal \& Anggraini (2010), bahwa kompetensi spiritual berpengaruh signifikan terhadap kinerja dan usaha atau bisnis. Akan tetapi, hasil penelitian ini konsisten dengan hasil penelitian Santoso dkk. (2017), yaitu kecerdasan spiritual tidak berpengaruh terhadap peningkatan usaha IKM. Ketidakberhasilan menemukan pengaruh signifikan ini terjadi karena beberapa hal seperti yang dinyatakan oleh Sumediyani (2011), yaitu ada beberapa hal yang menghambat berkembangnya kecerdasan spiritual dalam diri seseorang, diantaranya: 1) adanya ketidakseimbangan yang dinamis antara ide, ego, superego, dan ketidakseimbangan antara ego sadar yang rasional dan tuntutan dari alam tak sadar secara umum; 2) adanya orang tua yang tidak cukup menyayangi; 3) mengharapkan terlalu banyak; 4) Adanya ajaran yang mengajarkan menekan insting; $5)$ adanya aturan moral yang menekan insting alamiah; 6) adanya luka jiwa, yaitu jiwa yang menggambarkan pengalaman menyangkut perasaan terasing dan tidak berharga.

Jalil (2013), memaknai kecerdasan spiritual sebagai kemampuan untuk menghubungkan unsur-unsur spiritual dalam menyelesaikan masalah dalam kehidupan. Jadi semua yang dilalui dalam kehidupan ini adalah semata-mata pasti ada kaitannya dengan aspek spiritualitas manusia.

Dikaitkan dengan bisnis sistem paroan pada usaha penggemukan sapi di Sumenep, dapat dijustifikasi bahwa ada konteks bisnis sapi paroan, kompetensi spiritual tidak berhasil menemukan pengaruh signifikan terhadap perkembangan usaha. Pengusaha di bidang ini bisa jadi tidak terbiasa mengaitkan antara usaha yang digelutinya dengan spiritualitasnya. Hal ini dipicu biasanya rasionalitas yang secara alamiah tanpa sadar berperan lebih dominan.

Kompetensi Literasi Ilmu Pengetahuan: Konsep Keuntungan (X2) berpengaruh signifikan terhadap Perkembangan Bisnis Sistem Paroan (Y).

Berdasarkan hasil uji hipotesis yang sudah dilakukan, terdapat temuan bahwa literasi ilmu pengetahuan: kosep keuntungan berpengaruh signifikan terhadap perkembangan bisnis sistem paroan. Temuan ini diperkuat oleh beberapa penelitian sebelumnya yaitu Kaharti dkk. (2019), menyatakan optimalisasi laba berpengaruh signifikan terhadap pengembangan usaha. Sejalan dengan Arina (2015), bahwa salah satu tujuan usaha atau bisnis adalah memperoleh laba yang mana merupakan cerminan pertumbuhan harta atau pertumbuhan bisnis. Beberapa kajian tentang laba menunjukkan bahwa laba digunakan sebagai acuan yang penting dalam menilai suatu perusahaan (Andayani, 2006; Beaver, 1966). Laba juga seringkali digunakan sebagai indikator dalam menilai keberhasilan sebuah entitas bisnis (Mursy \& Rosidi, 2013).

Konteksliterasi ilmu pengetahuan pada bisnis sistem paroan, konsep keuntungan perlu dipahami secara menyeluruh oleh semua pihak yang terlibat dalam bisnis tersebut agar dapat meningkatkan keberhasilan dan perkembangan bisnis tersebut. Bisa dinyatakan bahwa jika investor dan penggemuk kompeten dalam optimalisasi laba dalam bisnis, maka dapat meningkatkan juga perkembangan bisnis sistem paroan di Sumenep tersebut. 


\section{Kompetensi Belajar untuk Belajar (X3) Berpengaruh Signifikan terhadap Perkembangan Bisnis Sistem Paroan (Y).}

Berdasarkan uji hipotesis, terdapat hasil kompetensi belajar untuk belajar berpengaruh signifikan terhadap perkembangan bisnis sistem paroan. Kompetensi diartikan sebagai pengetahuan, keterampilan dan kemampuan individu yang langsung berpengaruh pada kinerja(Fithri \& Sari, 2012). Dalam konteks bisnis, lebih lanjut Fithri \& Sari (2012) menjelaskan bahwa usahawan atau pebisnis yang sukses pada umumnya adalah mereka yang memiliki kompetensi yaitu jika dikembalikan kepada konsep kompetensi, adalah seseorang yang memiliki ilmu pengetahuan dan keterampilan di bidang bisnis serta kualitas individu itu sendiri yang meliputi sikap, nilai serta tingkah laku yang diperlukan untuk melaksanakan pekerjaan atau kegiatan.

Hasil penelitian ini diperkuat oleh Wei (2009), kompetensi yang dimiliki oleh seseorang yang menggeluti bisnis adalah: 1) kemampuan menganalisis secara sistematis; 2) kemampuan untuk mengambil peluang dan mengelola sumber daya yang ada; 3) kemampuan untuk menemukan kebutuhan internal dan eksternal dari konsumen; 4) kemampuan untuk belajar dan meningkatkan kompetensi yang dimiliki; dan 5) kemampuan untuk berkomunikasi. Berdasarkan pendapat tersebut, dapat dipahami bahwa kompetensi seseorang untuk selalu belajar secara berkelanjutan menjadi salah satu hal penting dalam menungjang keberhasilan bisnis dan perkembangan bisnis. Seseorang yang mampu belajar dari pengalaman setiap saat, yang mampu memperkaya diri terkait bidang bisnisnya sehingga semakin mahir dalam berbisnis di bidangnya, maka peluang untuk mengembangkan bisnisnya menjadi besar.
Kebutuhan Fisiologis (X4) Berpengaruh Signifikan terhadap Perkembangan Bisnis Sistem Paroan (Y).

Hasil uji hipotesis menunjukkan kebutuhan fisiologis berpengaruh signifikan terhadap perkembangan bisnis sistem paroan. Searah dengan (Dewi, 2018; Iskandar, 2016; Yonanda dkk., 2016), bahwa dorongan akan pemenuhan kebutuhan fisiologis atau kebutuhan dasar mempengaruhi prestasi kerja seseorang maupun semangat wirausahawan, sehingga linier dengan hasil penelitian ini. Kebutuhan fisiologis ini merupakan kebutuhan yang paling mendasar pada diri seseorang sesuai dengan teori motivasi yang dikemukakan oleh maslow. Kebutuhan fisiologis yaitu kebutuhan mempertahankan hidupnya secara fisik. Kebutuhan itu meliputi kebutuhan akan makanan, minuman, tempat tinggal, dsb.

Dalam konteks bisnis sistem paroan, kebutuhan fisiologis berpengaruh signifikan dikarenakan seseorang menjalankan bisnis sistem paroan atas dasar dorongan untuk berusaha memenuhi kebutuhan dasar hidupnya yaitu sandang, pangan, papan. Dorongan yang kuat inilah yang akhirnya membuat pebisnis sistem paroan berusaha untuk meningkatkan kapasitas usahanya dengan berbagai langkah-langkah yang dianggap efektif dan efisien dan berharap bisnis yang digelutinya tersebut dapat berkembang. Berangkat dari sinilah maka dorongan akan kebutuhan dasar atau fisiologis berpengaruh signifikan terhadap perkembangan bisnis sistem paroan.

\section{Kebutuhan Rasa Aman dan Keselamatan (X5) Tidak Berpengaruh terhadap Perkembangan Bisnis Sistem Paroan (Y).}

Hasil penelitian menunjukkan bahwa rasa aman dan keselamatan tidak berhasil penemukan pengaruh signifikan terhadap perkembangan bisnis sistem paroan. Hal ini tidak sejalan dengan penelitian 
Dewi (2018), yang menyatakan bahwa kebutuhan rasa aman dan keselamatan memberikan dorongan atau peningkatan motivasi untuk berwirausaha. Kebutuhan rasa aman yaitu kebutuhan akan perlindungan dari ancaman, bahaya, pertentangan dan lingkungan hidup, tidak dalam arti fisik semata, melainkan mental, psikologikal dan intelektual (Maslow dalam Dewi, 2018).

Dimensi dari kebutuhan rasa aman adalah adanya jaminan keselamatan kerja dan keamanan dari lingkungan pekerjaan, adanya dukungan untuk memperbaiki kehidupan di masa yang akan datang. Dalam konteks hubungan interpersonal bergantung pada banyak faktor, seperti keadaan cuaca atau situasi dalam melaksanakan pekerjaan atau suatu perlindungan dari ancaman seperti hujan, panas dan sebagainya. Beberapa hal kadang membuat perasaan cemas dan tidak aman.

Berbeda dengan hasil penelitian ini, pada konteks bisnis sistem paroan, kebutuhan akan rasa aman dan keselamatan tidak berpengaruh signifikan terhadap perkembangan bisnis. Hal ini dipicu beberapa hal berdasarkan telaah lebih detil terhadap hasil kuesioner, yaitu: 1) jarang ada pengalaman yang tidak menyenangkan terkait lingkungan yang tidak kondusif seperti cuaca, keamanan dan keselamatan hewan ternak dan sebagainya sehingga memungkinkan para pelaku bisnis di bidang ini tidak memikirkan hal rasa aman dan keselamatan; 2) para pelaku bisnis jarang menjumpai proses bisnis yang tidak selamat sehingga justru membuat kebutuhan akan hal ini dianggap sebagai kebutuhan yang biasa saja; 3) Berdasar pengalaman, bisnis ini dapat berjalan pada kondisi seperti apapun, cuaca berubah seperti apapun dan keadaan masysrakat seperti apapun sehingga bisnis ini tidak terlalu terpengaruh akan kebutuhan keamanan dan keselamatan. Mindset pemikiran akan kebutuhan ini sudah terpatri secara alamiah sehingga sampai tidak terpikirkan oleh pelaku bisnis sistem paroan.

\section{Kebutuhan Psikologis (X6) Tidak Berpengaruh terhadap Perkembangan Bisnis Sistem Paroan (Y).}

Hasil uji hipotesis menunjukkan bahwa kebutuhan psikologis tidak berpengaruh terhadap perkembangan bisnis sistem paroan. Hasil ini tidak sejalan dengan penelitian sebelumnya yaitu Nawawi (2011), bahwa dari segi psikologis kenyataannya menunjukkan bahwa bergairahnya atau bersemangatnya seseorang dalam melaksanakan pekerjaan sangat dipengaruhi oleh motivasi kerja yang mendorongnya. Salah satu temuan paling menarik dari riset-riset dengan pendekatan sifat/psikologi adalah tipologi wirausaha atau bisnis berdasarkan karakteristik psikologi mereka. Tipologi ini bermanfaat bagi pengembangan teori dan praktis (Husnam, 2017).

Berbeda dengan penelitian sebelumnya, pada konteks penelitian bisnis sistem paroan ini, kebutuhan psikologis tidak berpengaruh signifikan, artinya Perkembangan bisnis di sistem ini, tidak terlalu terpengaruh dengan psikologis pelaku bisnisnya. Pelaku bisnis pada tipe apapun, tidak terlalu merubah kondisi perkembangan bisnis pada sistem paroan ini. Hal ini dikarenakan pada konteks bisnis ini, berbagai tipe pelaku bisnis yang ada di lapangan, menunjukkan trend pengaruh perkembangan bisnis yang positif. Hal ini dijustifikasi dengan melihat berbagai karakteristik dan tipe pelaku bisnisnya.

\section{Hasil Pengujian Pendekatan Kualitatif - Fenomenologi}

Berdasarkan hasil kajian kuantitatif membutikan bahwa faktor keuntungan memiliki pengaruh yang sangat signifikan. Temuan ini bisa menjadi pembenar peneliti mengangkat topik menyingkap tabir "keuntungan" yang akan dikaji dalam sudut pandang akuntansi dan akan dikembangkan lebih lanjut dengan metode kualitatif sebagai pendukung (mix method). Embedded Correlation Model Creswell (2014), adalah model mix metod yang dipilih peneliti dalam mengembangkan riset ini. Dimana 
metode penelitian ini mencampurkan kedua pendekatan kuantitatif dan kualitatif secara tidak berimbang prosentasenya. Pendekatan kualitatif dengan embedded correlation model ini akan memperkuat atau mendukung riset kuantitatif yang telah dilakukan sebelumnya.

Informan yang dipilih dalam penelitian ini merupakan narasumber yang berkaitan dengan pengelolahan usaha ternak penggemukan sapi dengan sistem paroan. Informan utama adalah pihak peternak dan pemilik dana (investor) usaha penggemukan sapi yaitu bapak $H$. Buna'am dan bapak $\mathrm{H}$. Handoko Wijoyo, yang juga seorang investor dan juga sekaligus peternak yang aktif menggerakkan usaha budi daya penggemukan ini di desanya.

Melalui serangkaian analisis data dalam riset kualitatif fenomenologi antara lain tahapan (1) noema, (2) noesis, (3) ephoche, (4) intentional analysis, serta tahapan akhir yaitu (5) eidetic reduction, maka diperoleh hasil tentang berbagai makna keuntungan akuntansi yang timbul dari kegiatan sistem paroan penggemukan sapi Madura di daerah objek penelitian, sebagaimana diurai dalam penjelasan berikut.

\section{Keuntungan Materi: Dapat Penghasilan Utama, Tapi Bukan Segalanya}

Dari sudut pandang seorang informan yang merupakan seorang peternak sapi yang berusaha menggemukkan sapi orang lain, mendapatkan uang sebagai penghasilan memang adalah hal yang utama. Karena niat awalnya memang mereka mendapatkan uang dengan bekerja menggemukkan sapi dengan sistem paroan. Namun demikian ternyata ada keuntungan atau manfaat lain yang diperoleh selain materi, sebagaimana disampaikan Pak H. Buna'am:

Nyari rejeki itu wajib pak, pokoknya usaha, kalau tidak usaha mana bisa dapat uang. Percaya pada yang Kuasa pasti akan dikasih. Niat saya tapi nggak hanya nyari uang pak. Nggak banyak sebenarnya tapi saya dapat manfaat lain dari sapi ini.
Kalau hanya nyari uang tidak banyak kadang pak, tapi pokoknya seneng hati saya dan punya kegiatan setiap harinya. Itu penting pak biar tidak bingung saya.

Hal yang sama disampaikan oleh informan lain bernama pak $\mathrm{H}$. Handoko Wijoyo, bahwa memang disamping mendapatkan hasil uang dari usaha ini juga manfaat lain yang tidak kalah "bahagianya" dibandingkan dengan materi (uang) yang diperoleh.

Banyak mas untung lain selain uang, saya bisa bantu orang yang punya biar dapat pekerjaan. Padahal mereka nggak punya modal sama sekali, ya tetap saya bantu, seneng rasanya mereka bahagia. Saya ini jadi tempat curhatan tetangga kalua butuh apa-apa. Saya sebagai ketua kelompok usaha pingin semuanya punya usaha karena potensi banyak di desa ini.

Berdasarkan penuturan inroman jelas bahwa usaha budidaya penggemukan sapi Madura yang telah berlangsung berpuluh-puluh tahun lamanya ini sangat besar manfaatnya dan menghasilkan uang bagi hasil atau uang paroan yang cukup besar dan sangat dirasakan masyarakat. Meskipun tentu hasilnya beragam antara satu peternak dengan peternak lainnya. Ungkapan senada tentang hasil secara materi penggemukan sapi ini sebagaimana disampaikan oleh $\mathrm{H}$. Buna'am:

Saya ini pensiunan pak, dulu pernah jadi guru di SD. Untuk ngisi waktu saya ya sambil kerja ini. Seneng sekali saya dengan kegiatan ini, ya lumayan dapat penghasilan tambahan sehingga bisa cukup biaya kebutuhan bersama istri.

\section{Meraih Keuntungan Diatas Sekedar Materi:}

Manusia menurut Akhirudin (2015), akan senantiasa membutuhkan keseimbangan dalam menjalani kehidupannya. Meski materi menjadi awal motivasi bagi masyarakat peternak desa lalangon dalam melakukan usaha penggemukan sapi Madura dengan sistem paroan mereka memaknai secara luas dan tidak sekedar mengejar dunia materi. 


\section{Anugerah Produktivitas Masyarakat Secara Alami}

Faktor alam yang sejenis di suatu wilayah desa menurut Ningrum (2014), tentu akan sangat mempengaruhi tata kehidupan masyarakat. Potensi sumber daya alam, suasana dan kondisi cuaca suatu wilayah sangat mempengaruhi produktivitas dan keberagaman jenis usaha yang spesifik dengan lokasi tersebut.

Dengan sistem paroan kebanyakan masyarakat melakukannya sebagai bagian dari mata pencaharian mereka. Hal ini sebagaimana diutarakan oleh pak $\mathrm{H}$. Buna'am:

Rata-rata peternak sapi semua, karena disini jika tidak punya ternak sapi itu rugi, karena memanfaatkan ampas tahu itu. Disini ini makanan pokok sapi itu ampas tahu, bukan rumput. Makanya sapi bias lebih cepat gemuk jika ada di daerah desa lalangon ini pak.

Hampir semua peternak memanfaatkan potensi sumberdaya lokal yang ada untuk meningkatkan usaha sapi Madura

Bersyukur saya ada didesa ini, mumpung usaha sapi bisa lebih hemat dan sapi cepat gemuk jika menggunakaj ampas pabrik tahu yangg banyak tersedia di desa lalangon ini.

Untung sekali di desa ini ada usaha penggemukan sapi. Banyak manfaatnya melihara sapi ini, selain mengisi waktu luang, juga untuk olahraga secara gratis. Saya setiap saat bergerak angkat pakan, narik gerobak rumput, memberi pakan dan lainnya. Badan terasa selalu sehat dan bersemangat bekerja.

Lain lagi apa yang disampaikan pak $\mathrm{H}$. Handoko Wijoyo, dia menekankan bahwa suasana alam di desa ini benarbenar bermanfaat baginya dalam mencari penghidupan, membiaya keluarganya dan bisa memotivasi hidupnya dalam kesehariannya.

Kalau untuk saya usaha ini adalah utama pak, jadi disini ada yang utama ada yang sambilan, kebetulan saya sukwan guru disini.pulang ngajar saya bisa ngisi waktu nggak nganggur. Lumayanlah pak nambah-nambah uang untuk keluarga. Justru tidak melihara sapi yang jenuh, melihara sapi itu justru hiburan. Saya bias ngorol sama sapi, bias melihat perkembangn sapi, seneng lihat sapi saya sehat, gemuk dan bersih.

Ningrum (2014), bahwa semua potensi wilayah yang ada di daerah khususnya desa berupa sumber daya alam jika digunakan secara maksimal akan dapat meningkatkan kinerja atau produktivitas petani atau masyarakat desa setempat. Produktivitas yang dimaksud adalah meningkatnya pengetahuan, wawasan, penghasilan perubahan cara pandang dan pergaulan dari masyarakat desa di level yang lebih luas.

\section{Bersama-sama Beramal Akhirat: Jhak- Ajhak Kaangguy lbede}

Karakterisitik masyarakat desa yang masih kuat dalam tatan kehidupannya ditandai dengan tingkat solidaritas, kegotongroyongan, serta homogen dalam masalah mata pencaharian (Ningrum, 2014). Hasil riset Faraby (2016), menunjukkan bahwa kebersamaan dan etos kerjan yang tinggi dikarenakan bagi masyarakat setempat bekerja itu adalah ibadah sesuai petunjuk agama Islam. Maka tidak heran jika pernyataan pak $\mathrm{H}$. Handoko Wijoyo bahwa bekerja dalam penggemukan sapi itu saling membantu dan itu bernilai ibadah di mata Allah:

Tidak ada namanya saling iri, disini orang saling membantu, ada perkumpulan ternak juga disini, jadi ketika ada permasalahan dengan sapi, bisa saling didiskusikan, saling membantu. Misalnya ada sapi yang sakit, ini obatnya apa, harus bagaimana, itu bisa dikomunikasikan pada saat perkumpulan itu.

Pak H. Buna'am memperkuat apa yang disampaikan oleh pak Handoko bahwa dari bekerja penggemukan ini mereka akan bisa mengajak saudara, tetangga atau masyarakat lainnya di desa itu untuk bersama-sama. Mereka 
tidak sekedar bekerja sendiri namun akan memperhatikan saudara lainnya jika mengalami kendala.

Orang tua kami sejak dulu mengajarkan untk saling memperhatikan saudara, tetngga dan sanak family. Apalagi jika tinggal di satu desa yang sama pak. Entah mungkin karena sudah biasa ya pak, kami sering kumpul dan sering cerita satu sama lain tentang berbagai hal termasuk mata penghidupan.

Sungguh nilai-nilai yang muncul dari usaha penggemukan sapi ini tidak bisa lepas dari kekuatan masyarakat Madura yang sangat percaya kepada nilai-nilai agama disamping nilai etos kerja yang sangat tinggi (Tohirin, 2019). Dalam istilah Madura etos kerja yang tinggi ini dikenal dengan sebutan bharenteng atau semangat atau giat bekerjanya orang Madura, kar-ngakar colpe' yakni motivasi dan semangat kerja yang tetap tangguh dan keras, nyaronen yakni ikhtiar appun akan senantisa dilakukan dalam setiap usaha, serta jhak-ajhak yakni semangat rasa solidaritas yang tinggi serta kerjasama salaing membantu dalam bekerja (Faraby, 2016).

\section{Menyambung Saudara: Bennyak Tretan Odhi' Sajen Sennneng}

Teman atau kawan menurut Akin (2015), merupakan kekuatan atau sumber daya kognitif serta afektif yang dapat memunculkan harga diri serta meningkatkan kesejahteraan. Hasil riset membukti pernyataan tersebut bahwa persahabatan akan mempengaruhi tingkat kesejahteraan suatu individu dan tentu akan mempengaruhi penyesuaian psikologis (Mendelson \& Aboud, 1999).

Pak H. Buna'am merasa dengan makin bertambahnya teman yang dia temukan dari hasil usaha sapi ini meupakan keuntungan baginya.

Makin banyak hewan titipan artinya kita banyak dipercaya teman-teman, tetangga sendiri. Berarti banyak teman kita yang mau mempercayakan sapinya ke kita.
Saya ini malah jaga sapinya orang lain, dan anehnya sapi saya dititipkan ke orang lain. Entah karena memang keyakinan dan kebiasaan disini begitu sejak lama.

Pertemanan yang muncul dari kegiatan pengemukan sapi ini tentu sangat bermanfaat dalam kehidupan mereka. Sebagaimana disampaikan Anggraini (2017), bahwa pertemanan akan punya banyak bermanfaat diantaranya bisa menjadi penyemangat dalam menghadapi kehidupan dan bisa membantu menemukan tujuan hidup. Banyaknya manfaat pertemanan diakui Pak H. Handoko Wijoyo. Dari pertemanan tumbuh keinginan untuk saling berkumpul atau silaturhami secara rutin.

Adanya usaha penggemukan ini kami bisa sering kumpul rutin ngadain arisan, diskusi dan pengajian.masyarakat jadi rukun dan saling sapa satu sama lain.

\section{Menjunjung Warisan Budaya Desa}

Sejauh ini pemerintah masih memberi kepercayaan kepada pulau Madura sebagai kawasan budidaya sapi. Hal ini tidak lepas dari nilai kultur dan sejarah yang tinggi di mata orang Madura. Karena sapi Madura memiliki nilai kultural dan historis tinggi, sekaligus menjadi tabungan keluarga (Aziz, 2019).

Sapi sebagai salah satu tradisi di Madura menjadi bagian dari kehidupan masyarakat, termasuk salah satunya adalah usaha budidaya pengemukan sapi. Sebagaimana pak H. Buna'am menyampaikan tentang budidaya ini sebagai sebuah warisan budaya.

Sudah lama ini ada mas, sejak kakekkakek saya sudah diajarkan cara memelihara sapi agar gemuk. Tradisi leluhur kami, turun temurun pak istilahnya, kami hanya melanjutkan saja apa yang telah diwariskan orang tua

Tradisi kesenangan memelihara dan beternak sapi ibarat sudah menjadi keharusan dalam kehiduapn masyarakat Madura. Hal ini dibenarkan oleh pak $\mathrm{H}$. Handoko Wijoyo, bahwa sesungguhnya ini mereka hanya melanjutkan saja. 
Nggak tahu mas, sejak kecil karena diberitahu orang tua maka saya suka melihara sapi. Dulu waktu kecil diajak bapak bantu kasih makan sapi, nonton karapan, lomba sapi sonok. Pokoknya sudah sering lihat sapi saya itu.

Ciri khasnya adalah bahwa sapi yang dimiliki oleh peternak rata-rata bukan milik sendiri namun titipan orang lain yang mempercayakan kepada mereka. Pak Handoko kembali memberikan pernyataan pembenaran atas pernyataan ini.

lya benar disini ada kepercayaan yang sudah lama, kalau memelihara sapi sendiri biasanya tak jodoh, tapi kalau punya orang lain kok jodoh. Dipelihara sendiri itu tidak cocok, lebih cocok dipelihara orang lain, kurang telaten katanya.

\section{Sisi Lain Penggemukan Sapi: Kontribusi Pendapatan Rendah Ke Peternak}

Penghasilan dari seekor sapi saja dalam kurun waktu tiga bulan berkisar mendapatkan 1,4 hingga 1,6 juta saja. Sistem paroan penggemukan sapi ini dikatakan sebagai pekerjaan sampingan dikarenakan perolehan dari bagi hasil yang diterima sangat tidak mencukupi kebutuhan hidup kedua belah pihak terkhusus pihak peternak. Bagi pihak peternak yang memelihara sapi lebih banyak misal 5 ke atas, bagi hasil ini mungkin dapat menjadi pekerjaan utama.

Aziz (2019), berpendapat bahwa dalam usaha ternak atau penggemukan sapi Madura selama ini memang belum dapat mencukupi seluruh kebutuhan peternak secara maksimal. Paling tidak kontribusinya berkisar antara 18 sampai dengan 28 persen dari pendapatan keluarga.

Bahkan juga ada masyarakat yang motivasi memelihara sapi itu hanya sekedar memenuhi kesenangan atau hobi dalam memelihara sapi menurut pak $\mathrm{H}$. Buna'am.

lya benar betul sekali itu pak,meski kita dapat penghasilan itu, hasilnya tidak banyak mencukupi biaya keluarga. Pasti kami cari-cari dari yang lain. Kalau mengandalkan dari sapi saja kadang ndak cukup dan lama nunggunya.

Kalau mau lebih banyak bisa tapi capek, tenaga ini yang tidak mampu jaga sapi yang banyak lagi Coba hanya ngurus sapi masih bisa tapi kan ngurus yang lain juga. Kalau masih muda dan banyak orangnya bisa juga lebih dari 3 sapi.

Dari beberapa kali melihat kandang sapi warga memang hampir semua jumlahnya hanya 3 atau malah 2 ekor saja. Pak Handoko Wijoyo, lebih jauh menjelaskan mengapa hal ini terjadi:

Warga memang tidak banyak memelihara sapi pak, sebisanya memang. Banyak sih alasannya antara lain pakan sapi terbatas, ampas tahu itu juga kalua beli banyak ya berat bagi kita. Modalnya yang ndak cukup pak. Coba punya banyak ya bisa beli banyak juga.

Memang banyak faktor menurut Heryadi (2010), mengapa pada akhirnya usaha peternakan sapi di Madura khususnya belum bisa menghasilkan kontribusi yang maksimal bagi keluarga mereka. Ketersediaan pakan di musim kemarau adalah salah satu faktornya karea disaat itu mencari pakan sangat kesulitan. Industrilasisasi yang dimaksud dalam bidang peternakan rakyat adalah dengan cara menjadikannya sebagai usaha utama atau pokok pekerjaan bukan sampingan. Kemudian dikembangan pula tentang teknis perawatan, penggemukan dan pola makannya. Termasuk penyediaan pakan sapi secara regular perlu dipikirkan secara baik.

Secara terpisah pak Sutikno memberikan usulan yang sama yaitu mendorong agar usaha penggemukan sapi ini tidak lagi dijadikan usaha sampingan namun agar lebih berkontribusi secara ekonomi tidak lain dengan menjadikannya sebagai usaha utama keluarga.

Harusnya begitu, agar lebih optimal pekerjaannya bukan sampingan. Jika sampingan ya kesannya adalah sekedar ada waktu saja, tidak terlalu optimal mengurus dan mengoptimalkan waktu pengerjaan penggemukan sapi. 
Sekalian jika benar-benar serius kotoran dari sapi didaur ulang untuk menjadi bahan biogas untuk mengurangi beban lain dalam proses penggemukan.

Menurut saya minimal 5 sapi untuk setiap keluarga melakukan penggemukan sapi untuk bisa optimal dan bisa segera balik modal biaya lain yang dikeluarkan. Tentu tenaga kerja dari setiap keluarga harus focus mengurus sapi secara sungguhsungguh.

Upaya industrialisasi peternakan dengan melakukan perubahan teknis, manajemen, penyediaan pangan dan pola budidaya mau tidak mau merupakan satusatunya pilihan agar segera memberikan kontribusi riil dan optimal bagi para peternak itu sendiri. Cara-cara yang dapat dilakukan dengan arah industrialisasi peternakan sapi(Yusdja \& Ilham, 2007). Menurut Winarso(2015) jika industrialisasi peternakan diciptakan maka swasembada daging akan tercukupi secara nasional.

\section{SIMPULAN}

Hasil pengujian secara kuantitatif menunjukkan bahwa: konsep keuntungan, kompetensibelajar untuk belajar, kebutuhan fisiologis memiliki pengaruh signifikan terhadap perkembangan bisnis sistem paroan. Hal ini berarti sejalan dengan tema penelitian ini bahwa memang terdapat "keuntungan akuntansi" baik secara material dan non material. Adapun konsep bisnis paroan yang dijalankan selama ini dalam masyarakat meliputi (1) paroan uang hasil jual sapi setelah sapi cukup besar, cukup gemuk dan memang sudak layak untuk dijual. Kemudian (2) paroan hasil anak sapi yang lahir dari induknya jika memang memungkinkan karena jumlahnya lebih dari satu ekor anak sapi. Sedangkan prosentase pembagian selama ini beraneka ragam mulai dari 20-80, 50-50, 40-60 dan 60-40. Jenis keuntungan akuntansi yang telah diperoleh dalam penelitian ini terdiri dari dua yaitu berupa keuntungan material dan juga keuntungan non material. Keuntungan yang bersfiat material berupa uang hasil paroan penjualan sapi setelah sapi cukup layak untuk dijual dan menguntungkan. Kemudian materi lainnya berupa hasil anak sapi yang lahir dari induknya dan dibagi dua untuk pemilik modal dan peternak. Secara material tentu aktivitas ini sangat bermanfaat bagi para peternak dan pemilik modal, meski dipersepsikan berbedabeda yaitu ada menganggap sebagai hasil utama keluarga, hasil sampingan sebagai penambah penghasilan, serta sebagai hasil lain untuk tujuan tabungan di masa yang akan datang. Sedangkan nilai non material yang didapat dari usaha ini dirasakan sebagai bagian dari kehidupan sosial mereka di masyarakat antara lain (1) anugerah produktivitas masyarakat secara alami, (2) bersama-sama beramal akhirat, (3) menyambung saudara, (4) menjunjung warisan budaya desa, sedang temuan lain berupa (5) sisi lain penggemukan sapi: kontribusi pendapatan rendah ke peternak Keuntungan usaha penggemukan sapi dengan sistem paroan di Madura dalam perspektif materi dimaknai sebagai usaha mencari rejeki utama untuk keluarga, kemudian sebagai penghasilan tambahan, serta sebagai tabungan untuk masa depan. Sedangkan dalam perspektif non materi keuntungan adanya usaha penggemukan sapi dengan sistem paroan ini dimaknai sebagai (1) kesempatan yang wajib diikuti, mengisi waktu sambil berolahraga, waktu berguna tidak ngangur, dan ada hiburan (anugerah produktivitas masyarakat secara alami); (2) kesempatan membantu orang lain, bisa bergotong royong, maju bersama (bersama-sama beramal akhirat), (3) ajang pertemanan, pertemuan rutin dan arisan, memupuk kepercayaan pada warga lain (menyambung saudara), (4) bermakna melanjutkan tradisi leluhur, kegemaran memelihara sapi, kepercayaan menitipkan lebih baik dari memelihara sendiri (menjunjung warisan budaya desa) dan (5) sisi lain penghasilan belum maksimal tapi senang, pendapatan tidak maksimal katena alam, perlu fokus sebagai kerja utama bukan sampingan (kontrbusi penghasilan masih rendah). Dikarenakan banyak kendala dalam prakteknya untuk mendapatkan kontribusi secara 
maksimal dari usaha ini maka peneliti mengusulkan saran (1) Pemerintah daerah Kabupaten Sumenep perlu secara serius mengarahkan kepada seluruh peternak untuk benar-benar menjadikan usaha ini sebagai kerja utama dan professional, (2) perlu adanya perhatian secara sungguhsungguh dari pihak yang berwenang dalam mengatasi kendala ketersediaan pangan, (3) penelitian dan pengabdian masyarakat dari para akademisi berikutnya perlu diadakan agar dapat sedikit demi sedikit bisa mengatasi keterbatasan yang ada dalam usaha ini.

\section{DAFTAR PUSTAKA}

Abdoellah, O. S. (2020). Faktor-Faktor Yang Mempengaruhi Kebudayaan dan Berdampak terhadap Ekologi Manusia. Yayasan Abdurrahman Baswedan Timoho.

Akhirudin. (2015). Hidup Seimbang Hidup Bahagia (Cetakan ke). GemilangPustaka Alvabet.

Akin, A., \& Akin, U. (2015). Friendship Quality and Subjective Happiness: The Mediator Role of Subjective Vitality. Education and Science, 40(177), 233-242. https://doi. org/10.15390/EB.2015.3786.

Andayani. (2006). Analisis Kinerja BUMN yang Listed di BEJ Sebelum dan Sesudah di Privatisasi. Jurnal Akuntansi, Manajemen Bisnis, Dan Sektor Publik, 3(1). http://www. stiesia.ac.id/jurnal/index.php/journal/ list_journal/2/1/J201203.

Anggraini, A. P. (2017). Mengapa Kita Perlu Memiliki Teman? Kompas.com.

Arina, A. (2015). Pengaruh Beban Operasional, Pendapatan Operasional, dan Rasio Kecukupan Modal terhadap Pertumbuhan Laba Bersih PT Bank Muamalat Indonesia [IAIN Tulungagung]. http://repo.iaintulungagung.ac.id/1679/.
Auliyah, R. (2014). Studi Fenomenologi Peranan Manajemen Masjid AtTaqwa Dalam Pemberdayaan Ekonomi Masyarakat Bangkalan. Competence(Journal of Management Studies), 8(1), 74-91. https://doi.org/ https://doi.org/10.21107/kompetensi. v8i1.650.

Aziz, A. (2019). Sapi Madura, Antara Nilai Ekonomi dan Identitas Sosial. Antaranews.com. https://www. antaranews.com/berita/1105322/ sapi-madura-antara-nilai-ekonomidan-identitas-sosial.

Beaver, W. H. (1966). Financial Ratios as Predictors of Failure. Journal of Accounting Research, 4, 71$111 . \quad$ https://doi.org/https://doi. org/10.2307/2490171.

BPS. (2017). Populasi Sapi Potong menurut Kabupaten/Kota di Jawa Timur Tahun 2009-2017 (ekor).

Creswell, J. W. (2014). Research Design Pendekatan Kualitatif, Kuantitatif, dan Mixed (Edisi Keti). Pustaka Pelajar.

Dewi, R. D. L. (2018). Pengaruh FaktorFaktor Motivasi terhadap Kinerja Wirausaha Martabak Di Kecamatan Baleendah [Universitas Pasundan Bandung]. http://repository.unpas. ac.id/40117/.

Faraby, E. M. (2016). Etos Kerja Islam Masyarakat Etnis Madura. SALAM: Jurnal Sosial Dan Budaya Syar-I, 3(1), 21-38. https://doi.org/10.15408/ sjsbs.v3i1.3095.

Firmansyah, D., \& Sunyigono, A. (2020). Peran Kelembagaan pada Usaha Sapi Madura Ditinjau dari Aspek Kultural dan Struktural. Agriscience, 1(2). 
Fithri, P., \& Sari, A. F. (2012). Analisis Kompetensi Kewirausahaan Industri Kecil Suku Cadang di Kota Padang. Jurnal Optimasi Sistem Industri, 11(2), 279-292.

Guntoro, S. (2012). Membudidayakan Sapi Bali (Cetakan ke). Penerbit Kanisius.

Hafni, D. A. (2017). Studi Fenomenologi: Praktik dan Makna Akuntansi Bagi Wirausahawan Difabel Netra pada Usaha Mikro. Kompartemen (Jurnal IImiah Akuntansi), XV(2), 82-97. http://jurnalnasional.ump.ac.id/ index.php/kompartemen/.

Hardiansyah. (2013). Teori Pengetahuan Edmund Husserl. Substantia (Jurnal IImu-IImu Eshuluddin), 15(2), 228238. https://doi.org/http://dx.doi. org/10.22373/substantia.v15i2.4897.

Heryadi, A. Y. (2010). Bisnis Penggemukan (Fattening) Sapi Madura di Kabupaten Pamekasan [Universitas Pembangunan Nasional "Veteran" Jawa Timur]. http://eprints.upnjatim. ac.id/1501/1/File_1.pdf.

Husnam, N. A. (2017). Psikologi Kewirausahaan: Potensi Riset dalam Konteks Indonesia. The 6ᄀth University Research Colloquium.

Ikhsan, A., Baheri, \& Nuddin. (2018). Studi Praktik Bagi Hasil Antara Pemilik dan Pemelihara Sapi di Kelurahan Sendang Mulya Sari Kecamatan Tongauna Kabupaten Konawe. JEP (Jurnal Ekonomi Pembangunan), 8(1), 50-62. http://www.jep.uho@ uho.ac.id.

Iskandar. (2016). Implementasi Teori Hirarki Kebutuhan Abraham Maslom terhadap Peningkatan Kinerja Pustakawan. Jurnal IImu Perpustakaan, 4(1), 24-34.

Jalil, A. (2013). Spiritual Entrepreneurship (Studi Transformasi Spiritualitas Pengusaha Kudus). Institut Agama Islam Negeri Sunan Ampel Surabaya.
Kaharti, E., Artati, D., \& Susilowati, I. (2019). Analisis Kompetensi Pengelolaan Keuangan UMKM dalam Upaya Optimalisasi Laba, Pengembangan Usaha untuk Menciptakan Going Concern dalam Kompetisi Bisnis (Study Kasus pada UMKM Kabupaten Kebumen, Jawa Tengah). Prosiding Seminar Nasional Fakultas Ekonomi Untidar, 692-700. https://jurnal.untidar.ac.id/index.php/ semnasfe/article/view/2141.

Kamayanti, A. (2016). Metodologi Penelitian Kualitatif Akuntansi: Pengantar Religiositas Keilmuan (Cetakan Ke). Yayasan Rumah Peneleh.

Karnaen, \& Arifin, J. (2007). Kajian Produktivitas Sapi Madura (Study on Productivity of Madura Cattle). Jurnal IImu Ternak Universitas Padjadjaran (Journal of Animal Science Padjajaran University), 7(2), 135-139. https://doi.org/https://doi. org/10.24198/jit.v7i2.2247.

Kementan, P. D. (2018). Outlook 2018 Komoditas Pertanian Subsektor Peternakan Daging Sapi.

Kutsiyah, F. (2012). Analisis Pembibitan Sapi Potong di Pulau Madura. Wartazoa (Indonesian Bulletin of Animal and Veterinary Sciences, 22(3), 113-126. http://medpub. litbang.pertanian.go.id/index.php/ wartazoa/issue/archive.

Ludin, I., \& Saleh, S. (2018). Pengaruh Kecerdasan Intelektual, Kecerdasan Emosional, dan Kecerdasan Spiritual terhadap Kinerja Wirausaha Muslim di Kabupaten Purwakarta. Jurnal Ekonomi dan Bisnis, 8(1), 8-18. 
Mendelson, M. J., \& Aboud, F. E. (1999). Measuring Friendship Quality in Late Adolescene and Young Adults: McGrill Friendship Questionnaires. Canadian Journal of Behavioural Science / Revue Canadienne Des Sciences Du Comportement, 31(2), 130-132. https://doi.org/https://doi. org/10.1037/h0087080.

Mertens, D. M. (2010). Research and Evaluation in Education and Psychology: Integrating Diversity With Quantitative, Qualitative, and Mixed Methods. SAGE Publication.

Moleong, L. J. (2017). Metode Penelitian Kualitatif (Cetakan ke). PT Remaja Rosdakarya Offset.

Mursy, A. L., \& Rosidi. (2013). Sentuhan Rasa di Balik Makna Laba. Jurnal Akuntansi Multiparadigma, 4(1), 165-329. https://doi.org/http://dx.doi. org/10.18202/jamal.2013.08.7190.

Muyasaroh, S., Budisatria, I. G. S., \& Kustantinah. (2015). Income Over Feed Cost Penggemukan Sapi Oleh Kelompok Sarjana Membangun Desa (SMD) Di Kabupaten Bantul dan Sleman. Buletin Peternakan (Bulleting of Animal Science), 39(3), 205-211. https://doi.org/https:// doi.org/10.21059/buletinpeternak. v39i3.7989.

Nawawi. (2011). Manajemen Sumber Daya Manusia: Untuk Bisnis Yang Kompetitif. Gajahmada University Press.

Ningrum, E. (2014). Pendayagunaan Potensi Wilayah untuk Menigkakan Produktivitas Petani. Mimbar (Jurnal Sosial Dan Pembangunan), 31(2), 181-188. https://doi.org/https://doi. org/10.29313/mimbar.v30i2.706.

Nugraha, B. P. (2014). Perlakuan Akuntansi Aset Biologis pada Peternakan Sapi Perah (Studi Kasus Pada KPSP "Setia Kawan") [Universitas Jember]. http://repository.unej.ac.id/ handle/123456789/59255.
Nurlaila, S., Kurnadi, B., Zali, M., \& Nining, H. (2018). Status Reproduksi dan Potensi Sapi Sonok di Kabupaten Pamekasan. Jurnal IImiah Peternakan Terpadu, 6(3), 147-154.

Nurwahidah, Tolleng, A. L., \& Hidayat, M. N. (2015). Pengaruh Pemberian Pakan Konsentrat Dan Urea Molases Blok (Umb) Terhadap Pertambahan Berat Badan Sapi Potong. Jurnal IImu Dan Industri Peternakan, 2(2), 111-121. https://doi.org/https://doi. org/10.24252/jiip.v2i2.1564.

Paisal, \& Anggraini. (2010). Pengaruh Kecerdasan Emosional dan Kecerdasan Spiritual terhadap Kinerja Karyawan pada LBPP-Lia Palembang. Jurnal IImiah Orasi Bisnis, 4(1).

Paramiswari, R. D., \& Hayati, M. (2017). Pendapatan Usaha Ternak Sapi Madura (Studi Khasus Desa Kapedi Kecamatan Bluto Kabupaten Sumenep). Pamator (Jurnal IImiah Universitas Trunojoyo), 10(2), 107-111. https://doi.org/https://doi. org/10.21107/pamator.v10i2.4144.

Pratiwi, A. I., \& Sudaryanti, D. (2016). Akuntansi Karapan Sapi pada Masyarakat Madura dengan Pendekatan Etnografi. Jurnal IImiah Bisnis Dan Ekonomi STIE ASIA, 10(1), 6-9. https://doi.org/https://doi. org/10.32812/jibeka.v10i1.80.

Rahayu, E. T. (2013). Analisis Pendapatan Usaha Ternak Sapi Perah Di Kecamatan Cepogo Kabupaten Boyolali. Sains Peternakan (Jurnal Penelitian IImu Peternakan), 11(2), 99-105. https://jurnal.uns. ac.id/Sains-Peternakan/article/ view/4852/4194\#.

Richard, Clark, \& Cathey. (2020). Teori Akuntansi Keuangan: Teori dan Kasus (Edisi ke 1). Salemba Empat. 
Sahala, J., Widiati, R., \& Baliati, E. (2016). Analisis Kelayakan Finansial Usaha Penggemukan Sapi Simmental Peranakan Ongole dan Faktor-Faktor yang Berpengaruh terhadap Jumlah Kepemilikan pada Peternakan Rakyat Buletin Peternakan di Kabupaten Karanganyar. Buletin Peternakan (Bulleting of Animal Science), 40(1), 75-82. https:// doi.org/https://doi.org/10.21059/ buletinpeternak.v40i1.9823.

Sakri, N., Majid, J., \& Juardi, M. S. S. (2018). Mengungkap Informasi Akuntansi Usaha Kecil (Sebuah Studi Fenomenologi). Jurnal IImiah Akuntansi Peradaban, 4(2), 75100. https://doi.org/https://doi. org/10.24252/jiap.v4i2.6932.

Santoso, Rudi, Candraningrat, Binawati, \& Lilis. (2017). Elemen Kecerdasan Wirausaha untuk Meningkatkan Kinerja Industri Kecil dan Menengah (IKM) di Surabaya. Jurnal Bisnis Dan Manajemen (BISMA), 10(1), 73-89.

Subiyantoro, \& Triyuwono, I. (2004). Laba Humanis: Tafsir Sosial atas Konsep Laba dengan Pendekatan Hermeneutika (Edisi Pert). Bayu Media Publishing.

Sudarmono, A. S., \& Sugeng, Y. B. (2016). Panduan Beternak Sapi Potong. Penebar Swadaya.

Sumediyani, M. (2011). Kecerdasan Spiritual dan Problema Bangsa Ini. Www. Google.Com.

Sunarto, E., Nono, O. H., Lole, U. R., \& Henuk, Y. L. (2016). Kondisi Ekonomi Rumahtangga Peternak Penggemukan Sapi Potong Pada Peternakan Rakyat di Kabupaten Kupang. Jurnal Peternakan Indonesia (Indonesian Journal of Animal Science), 18(1), 21$28 . \quad$ https://doi.org/https://doi. org/10.25077/jpi.18.1.21-28.2016.
Tashakkori, A., \& Teddlie, Charles. (2010). Mixed Methodology: Mekombinasikan Pendekatan Kualitatif dan Kuantitatif. Pustaka Pelajar.

Themin, S. (2012). Akuntansi Keuangan (Edisi IFRS) (Edisi 8, J). Erlangga.

Tohirin, M. (2019). Nilai Budaya Madura pada Program Televisi J-Town di Net TV. JISIP: Jurnal IImu Sosial Dan IImu Politik, 8(1), 1-14. https:// publikasi.unitri.ac.id/index.php/fisip/ article/view/1524/1131

Triyuwono, I. (2017). Akuntansi Syariah: Perspektif, Metodologi dan Teori Akuntansi Syariah. PT. Rajawali Pers.

Ubaidillah, A., Mulyani, S., \& Effendi, D. E. (2013). Makna Keuntungan Bagi Pedagang Kaki Lima (Studi Pada Pedagang Kaki Lima di Bangsri Jepara). Jurnal Akuntansi \& Investasi, 14(1), 65-77. https://journal.umy. ac.id/index.php/ai/article/view/496.

Wei, W. W. (2009). A competency based Model for Success of An Entrepreneurial Start-up. Jurnal of WSEAS Transaction on Business and Economics, 6(6), 279-291.

Winarso, B. (2015). Peranan Ternak Dalam Menopang Ekonomi Rumah Tangga Di Perdesaan Pada Wilayah Agroekosistem Perkebunan, Panel Petani Nasional: Rekonstruksi Agenda Peningkatan Kesejahteraan Petani. Media Neliti Journal. https://media.neliti.com/media/ publications/710-ID-peranan-ternakdalam-menopang-ekonomi-rumahtangga-di-perdesaan-pada-wilayahagr.pdf.

Yarmunida, M. (2018). Dimensi Syariah Compliance Pada Operasional Bank Syariah. Al Intaj - Jurnal Ekonomi Dan Perbankan Syariah, 4(1). 
Yonanda, C., Susilo, H., \& Arik, P. (2016). Yusdja, Y., \& Ilham, N. (2007). Suatu Pengaruh Kebutuhan Fisiologis, Keamanan, Sosial, Penghargaan, dan Aktualisasi Diri terhadap Prestasi Kerja Karyawan (Studi pada Karyawan PT Asuransi Jiwasraya (Persero) Malang Regional Office). Jurnal Administrasi Bisnis, 30(1). http://administrasibisnis. studentjournal.ub.ac.id/index.php/ jab/article/view/1194. Gagasan tentang Peternakan Masa Depan dan Strategi Mewujudkannya. Forum Penelitian Agro Ekonomi, 25(1), 19-28.

Zahri, \& Haryadi. (2019). Sapeh Sonok (Sokonah Nongkok): Mengungkap "Laba Lain" Dalam Perspektif Pemilik. Prosiding Seminar Nasional Dan Call for Paper V. 